\title{
PELATIHAN MEMBUAT TAHU YANG SEHAT PADA WKRI PAROKI ST. MARIA FATIMA, SENTUL CITY, BOGOR
}

\author{
Tati Barus, Yasinta Ratna Esti Wulandari, Rory Anthony Hutagalung, Agustin Wydia \\ Gunawan
}

\author{
${ }^{1}$ Fakultas Teknobiologi, UNIKA Atma Jaya Jakarta \\ Jalan Raya Cisauk-BSD, Tangerang 15345, Indonesia \\ tati.barus@atmajaya.ac.id \\ yasinta.ratna@atmajaya.ac.id \\ rory.hutagalung@atmajaya.ac.id \\ agustin.gunawan@atmajaya.ac.id
}

\begin{abstract}
ABSTRAK
Tahu merupakan makanan tradisional Indonesia yang memiliki banyak keunggulan sebagai bahan pangan dan proses pembuatannya sangat sederhana. Namun demikian, pengetahuan masyarakat tentang tahu dan cara membuat tahu yang sehat masih rendah. Oleh sebab itu, pengabdian pada masyarakat ini bertujuan untuk meningkatkan pengetahuan masyarakat tentang tahu sebagai makanan yang sehat dan cara pembuatan nya. Kegiatan pengabdian dilakukan pada warga WKRI Paroki St. Maria Fatima, Sentul City, Bogor 16810 dengan menggunakan metode penyuluhan, demonstrasi, dan pendampingan. Monitoring dilakukan untuk mengukur tingkat keberhasilan peserta dalam memproduksi tahu sehat. Persepsi peserta tentang tahu dievaluasi melalui metode survei dan peningkatan pengetahuan diukur melalui test (pretest dan post test). Hasil penyuluhan, demonstrasi, dan pendampingan berhasil meningkatkan keterampilan peserta yang terlihat dari keberhasilan peserta dalam mengikuti prosedur pembuatan tahu. Hasil tersebut juga diperkuat oleh hasil monitoring dimana seluruh peserta berhasil membuat tahu yang sehat. Hasil survei menunjukkan peningkatan pengetahuan peserta tentang tahu sehat dan peningkatan motivasi peserta dalam memproduksi tahu sehat secara mandiri. Penilaian peserta tentang jalannya kegiatan pengabdian sangat baik terutama dalam meningkatkan pengetahuan ( $89 \%$ menyatakan sangat setuju dan sisanya setuju). Kemampuan fasilitator dalam menyampaikan materi juga dinilai baik oleh peserta (53\% menyatakan sangat setuju dan sisanya setuju). Sebagai tindak lanjut peserta menyatakan bahwa mereka akan membagikan pengetahuan kepada teman dan keluarga. Salah satu bukti nyata dari keberhasilan pelatihan ini ialah salah satu peserta yang menjadi pengusaha tahu.
\end{abstract}

Kata kunci: ibu rumah tangga, kedelai, fermentasi, makanan sehat, tahu

\section{PENDAHULUAN}

Kedelai merupakan jenis kacang kacangan yang paling banyak digunakan sebagai bahan pangan. Hal ini karena kedelai mengandung protein paling tinggi $\pm 40 \%$, selebihnya karbohidrat $\pm 35 \%$, lemak $\pm 20 \%$ dan \pm abu $5 \%$. Khususnya di Asia, kedelai banyak difermentasi menjadi bahan pangan seperti kinema di India dan Nepal (Sarkar et al. 2002), cheonggukjang (Korea) (Kwon et al. 2009), dawadawa (Terlabie et al. 2006), dan soumbala (Afrika) (Sarkar et al. 2002), natto (Jepang) (Hsu et al. 2009), tempe dan tauco di Inonesia. Beberapa jenis bahan pangan tersebut saat ini sudah dikategorikan sebagai bahan pangan fungsional sebab bukan saja mengandung zat gizi yang baik, namun juga mengandung senyawa bioktif yang baik untuk kesehatan.

Pada awalnya kedelai dibudidayakan di China khususnya daerah China Utara. Seiring dengan migrasi orang China maka kedelai dibawa ke beberapa negara di wilayah lainnya seperti Indonesia, Filipina, Vietnam, Thailand, Malaysia, Burma, Nepal, dan India. Dari China kedelai juga dibawa ke Eropa dan Amerika pada abad 18. Saat ini kedelai dapat ditemui dengan mudah diberbagai belahan dunia. Inovasi pengolahan kedelai menjadi beberapa jenis makanan fermentasi juga banyak berasal dari dari China.

Tahu merupakan salah satu jenis makanan yang popular dari kedelai yang banyak diproduksi sebagai sumber nutrisi dan diminati oleh masyarakat Indonesia. Karyasa (2000) melaporkan saat ini sekitar 10\% masyarakat Indonesia mengkonsumsi tahu sebanyak 100 gram per hari. Rata-rata 
konsumsi tahu tersebut terus mengalami peningkatan dari tahun ke tahun. Hal ini karena kandungan nutrisinya yang baik, cita rasanya enak, mudah di dapat dan pengolahannya relatif mudah. Tahu merupakan bahan pangan sumber protein yang harganya relatif murah dibandingkan bahan pangan sumber protein lain seperti telur, daging dan ikan.

Isu pemakaaian formalin pada tahu sebagai pengawet menimbulkan rasa khawatir sehingga timbul rasa khawatir masyarakat untuk mengkonsumsi tahu. Penggunaan formalin yang merupakan cairan pengawet berbahaya bagi kesehatan telah diinformasikan secara luas. Formalin tidak berwarna dan mempunyai bau yang keras dan mempunyai berat jenis $1,09 \mathrm{~kg} / \mathrm{L}$ dalam suhu 20 derajat Celsius. Penelitian Badan Pengawas Obat dan Makanan (BPOM) menunjukkan bahwa adakalanya formalin ditemukan pada makanan yang sehari-hari yang kita konsumsi. Misalnya mi basah, ikan asin, bakso dan tahu. Bahkan terakhir formalin ditemukan pada kikil, makanan favorit sebagian masyarakat Indonesia. Formalin bagi tubuh manusia diketahui sebagai zat beracun, karsinogen (menyebabkan kanker), mutagen (menyebabkan perubahan sel), korosif dan iritatif," Dampaknya berbagai upaya dilakukan kelompok masyarakat untuk menghindari konsumsi makanan yang menggunakan senyawa berbahaya tersebut.

Oleh karena itu, warga yang berada pada WKRI Paroki St. Maria Fatima, Sentul City, Bogor meminta Fakultas Teknobiologi UNIKA ATMA JAYA untuk membimbing mereka dalam pembuatan tahu. Tujuannya agar mereka dapat membuat tahu guna dikonsumsi sendiri maupun untuk dijual sebagai usaha menambah pendapatan keluarga.

\section{METODE PELAKSANAAN}

Pelatihan pembuatan tahu pada kegiatan ini dilakukan oleh masyarakat yang tergabung dalam warga WKRI Paroki St. Maria Fatima, Sentul City, Bogor 16810 yang dibimbing oleh Tim dosen (narasumber) Fakultas Teknobiologi, Universitas Katolik Indonesia Atma Jaya. Seorang tokoh WKRI Paroki St. Maria Fatima, Sentul City, Bogor, yaitu Ibu Yemima Mariana Sidabutar yang merupakan Kabid KESRA, WKRI Cabang Sentul ini mengajak teman-temannya yang ingin membuat tahu sendiri dan meminta narasumber dari Fakultas Teknobiologi UNIKA Atma Jaya sebagai pembimbing. Kegiatan diawali dengan penyampaiam keinginan peserta kepada salah satu dosen dari Fakultas Teknobiologi. Selanjutnya, penyampaian keinginan tersebut dilakukan melalui pengiriman surat kepada Dekan Fakultas Teknobiologi.

Kegiatan terdiri atas beberapa tahapan pelaksanaan, yaitu: tahap 1) pengisian kuestioner oleh peserta, tahap 2) memberikan penjelasan tentang manfaat makanan kedelai termasuk tahu bagi kesehatan, tahap 3) memberikan penjelasan tentang cara membuat tahu, tahap 4) memberikan pembimbingan dan diskusi dalam pembuatan tahu langsung dengan peserta, tahap 5) memberikan pembimbingan dan diskusi dalam pembuatan tahu melalui media sosi melalui media sosial (whatsapp/WA), dan tahap 6) evaluasi hasil kegiatan melalui media sosial (WA).

Tahapan 1 sampai tahap 4 dilaksanakan pada hari Sabtu, tanggal 24 Februari 2018 di Sentul Bogor. Tahap 5 dan tahap 6 dilakukan melalui media sosial WA setelah demontrasi pembuatan tahu dilakukan pada tanggal 24 Februari tersebut. Tujuannya agar para narasumber tetap dapat memonitor keberhasilan mitra dalam memproduksi tahu secara mandiri. Monitoring dilanjutkan untuk memantau penyebarluasan kegiatan pada kelompok masyarakat lain oleh mitra peserta.

Pada tahap 1 peserta diberi lembar pertanyaan yang harus dijawab yang berisi tentang identitas peserta, persepsi peserta tentang tahu, dan pertanyaan terbuka dari peserta. Materi tahap 2 diberikan dengan topik "Manfaat tahu sebagai makanan sehat: Mari Memproduksinya Sendiri" 
yang dibawakan oleh Dr. Ir. Tati Barus, M.Si. Selanjutnya diberikan materi tahap 3 tentang "Cara membuat tahu". Pelaksanaan tahap 2 dan tahap 3 berlangsung sekitar 20 menit dengan presentasi menggunakan salindia dan 25 menit tanya jawab (diskusi). Materi tahap 2 dan tahap 3 diberikan juga dalam bentuk hard copy kepada setiap peserta.

Tahap 4, yaitu memberikan pembimbingan dan diskusi dalam pembuatan tahu secara langsung dengan peserta berlangsung sekitar 90 menit. Bahan dasar pembuatan tahu terdiri atas $4 \mathrm{~L}$ air layak minum, $250 \mathrm{~g}$ biji kedelai kuning, $20 \mathrm{~mL}$ asam cuka makan atau $1 \mathrm{~L}$ air asam bekas pembuatan tahu, $1 \mathrm{~m}$ kain kasa putih untuk menyaring dan membungkus tahu. Alat yang digunakan yaitu blender untuk membuat bubur kedelai, panci ukuran $6 \mathrm{~L}$ untuk merebus bubur kedelai, saringan santan ukuran diameter 15-20 $\mathrm{cm}$ atau dapat menggunakan kain kasa, cetakan tahu atau wadah plastik yang berlubang-lubang ukuran $30 \mathrm{~cm}$ x $15 \mathrm{~cm}$, kompor untuk memasak, sendok pengaduk, serbet, dan kertas tisu.

Proses pembuatan tahu diawali dengan merendam biji kedelai selama 4 jam yang telah dilakukan sebelumnya, lalu biji kedelai dimasukkan ke dalam blender dan diaduk kencang hingga menjadi bubur kedelai. Bubur kedelai kemudian direbus hingga mendidih, lalu ditambahkan kembali 1 gelas air dingin ke dalamnya dan diaduk. 1 gelas air dingin ditambahkan kembali dan diaduk hingga total menjadi 4 gelas air. Bubur kedelai direbus sekitar 30 menit dengan api kecil, kemudian disaring dengan kain kasa untuk mendapatkan susu kedelai yang selanjutnya diolah menjadi tahu.

Susu kedelai yang telah diperoleh dicampur dengan asam cuka dan diaduk secara perlahan-lahan. Susu kedelai kemudian akan menggumpal dan dituang ke dalam saringan kain kasa. Bagian yang padatan pada kain kasa dipindahkan ke dalam cetakan tahu dan ditekan selama 20 menit sehingga terbentuk tahu sesuai bentuk cetakan yang digunakan. Selanjutnya tahu sudah berhasil diproduksi.

Setelah proses pembuatan tahu dilakukan maka peserta diminta mengulangnya kemabali di rumah masing masing. Hasil yang diperoleh dilaporkan peserta kepada narasumber melalui grup WA yang dibuat yang beranggotakan semua peserta. Kelanjutan kegiatan yang dilakukan oleh peserta dipantau dan diidskusikan melalui grup WA tersebut.

\section{HASIL DAN DISKUSI}

Pertimbangan utama yang perlu dipikirkan dalam pelaksanaan kegiatan pengabdian kepada masyarakat ialah keberlanjutan (sustainabitlity) dan dampak dari kegiatan yang akan dilakukan. Untuk kegiatan pembuatan tahu, ibu-ibu merupakan sasaran yang tepat mengingat kodrat yang menggariskan bahwa salah satu fungsi tradisionil ibu-ibu ialah memasak. Dari segi agen perubahan, ibu-ibu merupakan aktor yang paling berperan dalam penyebaran berita dan pengadaan perubahan. Ibu-ibu juga merupakan kelompok yang memiliki komunitas sosial baik fisik maupun virtual yang relatif luas. Dengan demikian penyebaran informasi melalui kelompok ibu-ibu cepat dan memiliki jangkauan yang luas.

Diskusi awal yang dilakukan dengan peserta ditemukan adanya keinginan yang besar untuk meproduksi tahu sendiri namun belum mempunyai ketrampilan untuk memproduksinya. Keinginan untuk memproduksi tahu sendiri didasari oleh hasrat untuk mengonsumsi tahu yang sehat dan higienis. Hal ini karena beredarnya informasi tentang adanya tahu produksi tertentu yang mengandung bahan kimia yang berbahaya bagi tubuh.

Sebagian besar peserta merupakan wanita karir (bekerja) dan hanya 38\% yang berstatus sebagai ibu rumah tangga. Tingkat pendidikan peserta relatif tinggi dimana mayoritas peserta ialah lulusan 
perguruan tinggi. Mayoritas peserta sudah menikah. Dari segi suku, majoritas peserta ialah suku jawa (62\%), diikuti oleh suku batak (23\%) dan $15 \%$ lainnya dari suku-suku lain. Dalam pelatihan ini tidak hanya dihadiri ibu-ibu saja tetapi beberapa pemuda dan bapak-bapak juga turut hadir dan melakukan praktik.

Kegiatan pengabdian berjalan dengan baik. Kegiatan utama pada tanggal 24 Februari 2018 dihadiri oleh seluruh peserta dan mulai dengan tepat waktu, yakni pukul 09.00 WIB dan sampai acara berakhir tidak satupun peserta yang meninggalkan tempat. Peserta yang hadir berjumlah 43 orang.

Acara diawali dengan pembukaan dan dilanjutkan presentasi oleh narasumber mengenai Tahu yang ditinjau dari manfaatnya berdasarkan kajian ilmiah serta penjelasan mengenai pembuatan tahu secara higienis (Gambar 1). Kepada peserta juga dijelaskan terlebih dahulu jenis-jenis kedelai yang ada, komposisi kedelai, macam-macam pengolahan kedelai, pengetahuan tentang formalin yang biasa digunakan untuk mengawetkan tahu dan mengapa tahu dapat disebut sebagai makanan sehat.

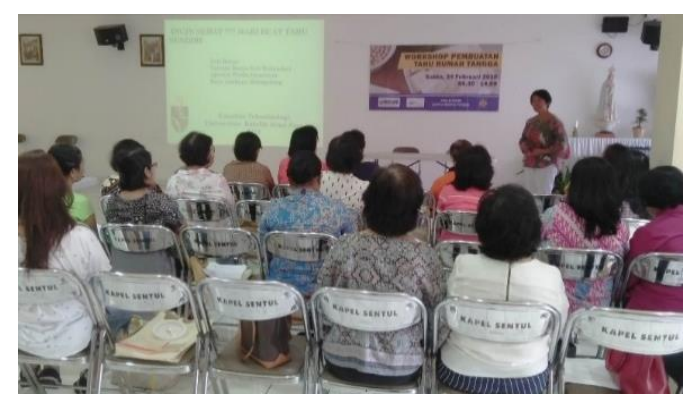

Gambar 1. Ceramah peningkatan pengetahuan tentang tahu sehat

Informasi tentang tahu sebagai makanan sehat dan cara pembuatannya dari nara sumber menambah keinginan peserta untuk memproduksi tahu sendiri secara higienis. Hal tersebut terlihat dari antusiasme dan kedalaman diskusi dan banyaknya pertanyaan yang diajukan oleh peserta. Misalnya seperti pertanyaan yang diajukan ialah tentang kemungkinan penggunaan bijianbijan lain selain kedelai sebagai bahan baku tahu.

Setelah diskusi, acara dilanjutkan dengan demontrasi pembuatan tahu. Peningkatan ketrampilan membuat tahu dilakukan dengan metode demonstrasi dan pendampingan. Selanjutnya peserta mempraktikkan sendiri pembuatan tahu. Untuk memperlancar acara pada waktu pelatihan, segala bahan dan alat sudah disiapkan oleh mitra yang dikoordinir oleh Ibu Yemima, sehingga peserta bisa langsung praktik.

Berhubung dengan jumlah peserta yang banyak (43 orang) maka untuk memudahkan praktik, peserta dibagi ke dalam tiga kelompok, yang diberi nama kelompok A, kelompok B dan kelompok C. Pembuatan tahu diawali perendaman kedelai selama 4 jam yang sudah dilakukan sebelumnya oleh panitia (Gambar 2). Kemudian kedelai diblender dengan 6 gelas air hingga menjadi bubur kedelai (Gambar 3). Hal ini dilakukan oleh masing-masing kelompok. Harapannya agar nanti para peserta dapat mandiri membuat tahu sendiri. Pada saat demontrasi pembuatan tahu para nara sumber ikut aktif membaur dengan peserta, untuk menjelaskan secara detail proses pembuatan tahu tersebut. 


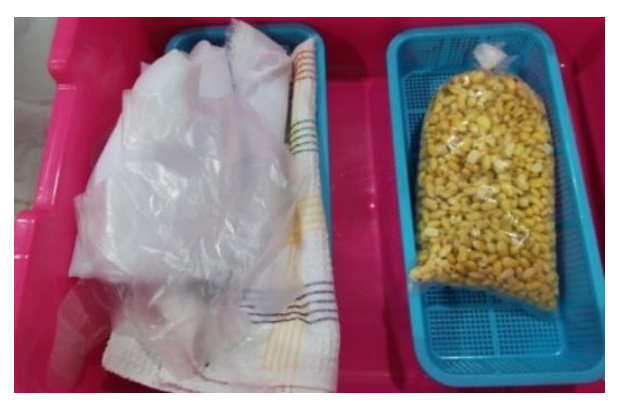

Gambar 2. Kedelai yang sudah direndam selama 4 jam dan ditiriskan

Setelah diblender, kedelai direbus hingga mendidih. Selama perebusan, para peserta dibimbing cara menamambah air 1 gelas air dingin pada setiap tahapnnya. Hal ini dimaksudkan agar peserta mahir dalam proses ini karena tahapan ini hal penting dalam pembuatan tahu. Proses perebusan bubur kedelai berlangsung sekitar 30 menit dengan api sekecil mungkin (Gambar 4).

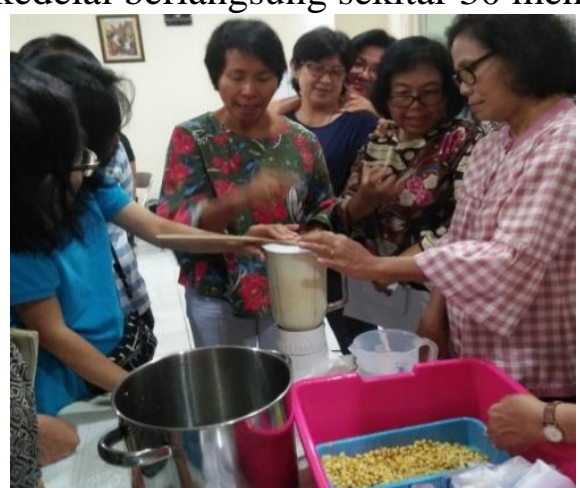

Gambar 3. Kedelai diblender menjadi bubur kedelai

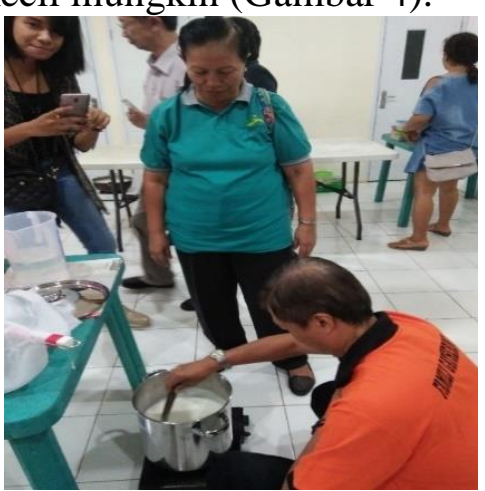

Gambar 4. Proses perebusan bubur kedelai

Setelah direbus, bubur kedelai kemudian disaring dengan kain kasa Gambar 5). Cairannya ditampung sebagai susu kedelai yang akan diolah selanjutnya menjadi tahu. Pada kegiatan ini diinformasikan juga kepada peserta bahwa ampas hasil saringan bubur kedelai tersebut masih mengandung nutrisi dan serat yang baik bagi kesehata. Oleh sebab itu dapat diolah menjadi bahan makanan lain.

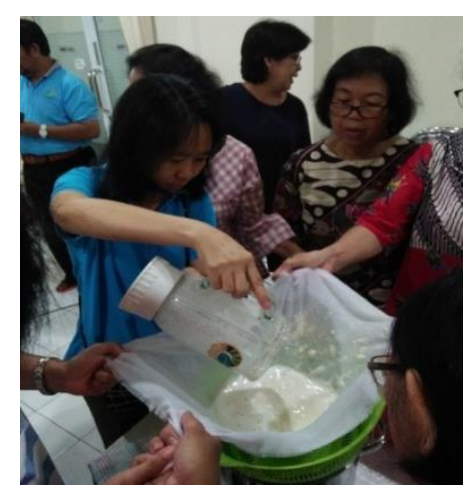

Gambar 5. Penyaringan bubur kedelai menggunakan kain kasa

Setelah susu kedelai berhasil diperoleh, kemudian asam cuka dapur ditambahkan sekitar $20 \mathrm{ml}$ secara perlahan-lahan sambil diaduk. Proses ini akan akan menggumpalkan susu kedelai (Gambar 6). Pada tahapan ini diberi penjelasan mengapa pengasaman dapat menyebabkan penggumpalan 
pada susu kedelai sehingga terbentuk 2 fase terpisah. Air yang terpisah di bagian atas yang akan dibuang dan gumpalan dipanen dengan disaring dengan kain kasa secara perlahan dengan menempatkannya pada cetakan. Sesuai dengan topik yang dilakukan yaitu skala rumah tangga, alat-alat yang digunakan semua merupakan perkakas rumah tangga, dalam hal ini digunakan semacam keranjang plastik berbentuk persegi panjang sebagai cetakan tahunya (Gambar 7).

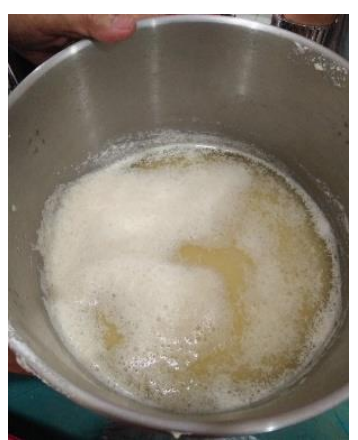

Gambar 6. Susu kedelai yang menggumpal akibat asam cuka dapur

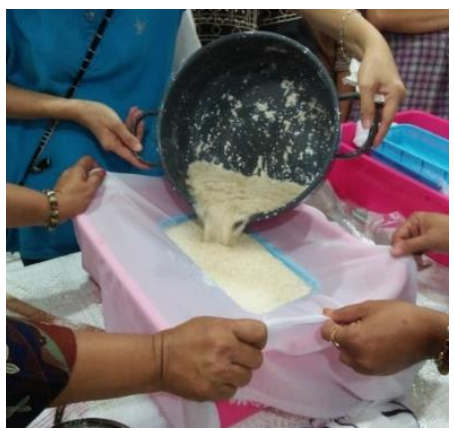

Gambar 7. Pencetakan tahu menggunakan peralatan rumah tangga

Bagian padat akan tertinggal pada keranjang plastik yang berlubang-lubang. Gumpalan susu kedelai ditekan sampai tidak ada lagi cairan yang keluar selama 20 menit dan menjadi bentukan yang padat seperti tahu (Gambar 8).

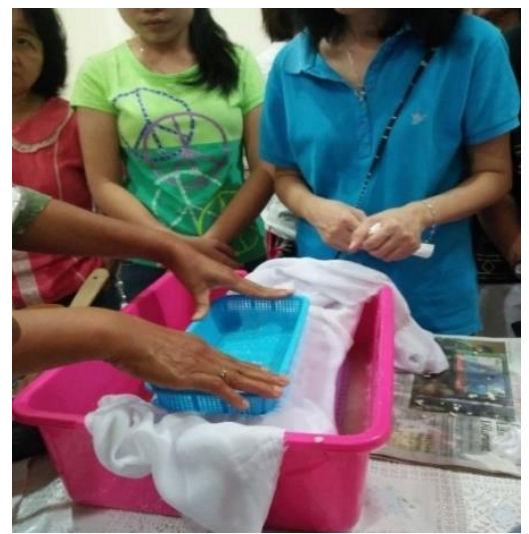

Gambar 8. Penekanan dengan keranjang plastik untuk mengeluarkan cairan yang tertinggal

Pada kegiatan ini semua kelompok berhasil membuat tahu (Gambar 9). Namun tekstur tahu yang diperoleh masing masing kelompok tidak sama. Tahu dari kelompok A terlihat lebih halus dan lembut daripada 2 kelompok lainnya. Dilihat dari proses pembuatannya, memang bubur kedelai dari kelompok A ini lebih hancur dan lembut dibanding 2 kelompok lainnya. Tahu dari kelompok lainnya terlihat kurang halus, hal ini dapat dikarenakan waktu penambahan asam cuka yang kurang perlahan-lahan. Penambahan asam cuka yang perlahan-lahan sambil diaduk akan menyebabkan penggumpalan susu kedelai yang lebih halus. Telah dilaporkan proses pengadukan saat pembuatan tahu (tofu) sangat menentukan kualitas (Rekha dan Vijayalakshmi 2013). 


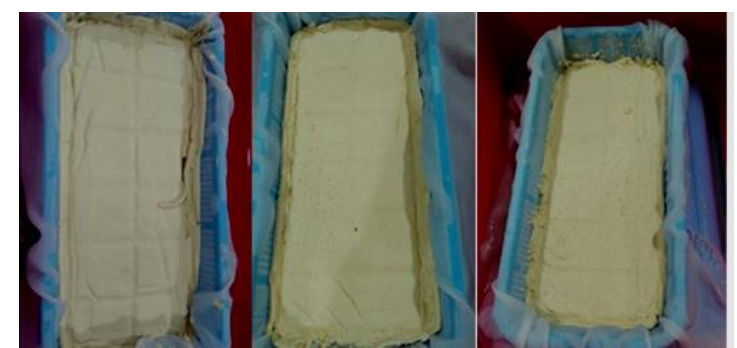

Gambar 9. Hasil cetakan tahu dari peserta: kelompok A (kiri), kelompok B (tengah), kelompok C (kanan)

Setelah diiris-iris, kemudian potongan tahu direbus ke dalam air mendidih selama 20 menit. Tahu yang baik dicirikan oleh warna putih, empuk, halus dan padat (Gambar 10). Dari Gambar 10 tampak bahwa tahu kelompok A hancur. Hal ini dapat diakibatkan karena susu kedelai yang kurang menggumpal karena asam cuka dapur yang kurang ditambahkan dan proses pengadukan yang belum mahir. Tahu kelompok B yang paling baik hasilnya. Terlihat dari tahu yang padat dan tidak hancur. Tahu kelompok $\mathrm{C}$ juga dapat dikatakan berhasil, tapi masih kurang baik karena sebagian tahu hancur. Hal ini dapat diakibatkan oleh penambahan asam cuka yang kurang pas takarannya dan pengadukan yang belum mahir. Dari segi rasa, tahu kelompok $\mathrm{C}$ dinilai paling enak karena rasa asamnya cukup dibandingkan 2 kelompok lainnya. Saat demontrasi pembuatan tahu diinformasikan juga bahwa pada saat perebusan tahu dapat juga ditambahkan garam agar memberikan cita rasa lebih gurih.

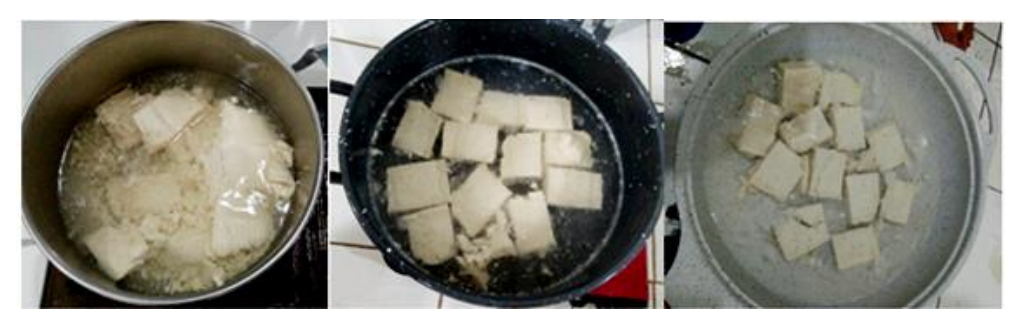

Gambar 10. Tahu direbus dalam air mendidih: kelompok A (kiri), kelompok B (tengah), kelompok C (kanan)

Keberhasilan pelatihan juga diukur melalui persepsi peserta dan peningkatan pengetahuan peserta tentang tahu yang diukur melalui pretest dan posttest. Secara keseluruhan kegiatan pelatihan berhasil mengarahkan persepsi peserta tentang tahu ke arah yang positif dan berhasil meningkatkan pengetahuan peserta tentang tahu. Seluruh peserta menyatakan bahwa semakin meningkat pengetahuan mereka tentang tahu merupakan makanan yang sehat dengan proporsi $28 \%$ menyatakan setuju dan $72 \%$ menyatakan sangat setuju (Gambar 11). Tak satupun peserta yang menyatakan tidak setuju atau sangat tidak setuju.

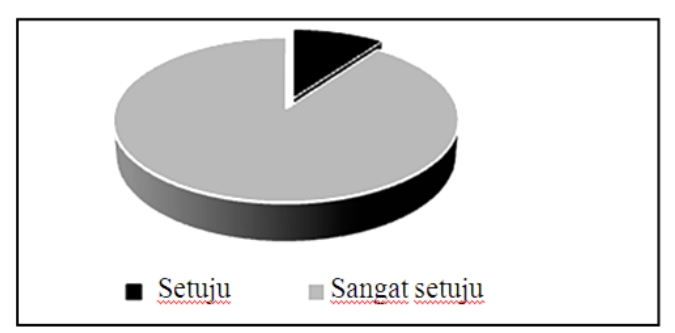

Gambar 11. Persepsi peserta tentang tahu merupakan makanan yang sehat 
Persepsi tersebut tentang tahu merupakan makan sehat kelihatannya berimbas pada sikap peserta untuk mengonsumsinya dimana $58 \%$ peserta menyatakan sangat setuju bahwa tahu merupakan makanan bergizi dan oleh karenanya perlu dikonsumsi secara rutin dan $31 \%$ menyatakan setuju dan hanya $11 \%$ yang menyatakan tidak setuju (Gambat 12). Kedua persepsi positif tersebut juga tergambar pada pendapat tentang pelestarian tahu. Seluruh peserta (28\% setuju dan $72 \%$ sangat setuju) mengatakan bahwa tahu merupakan makanan yang perlu dilestarikan (Gambar 13).

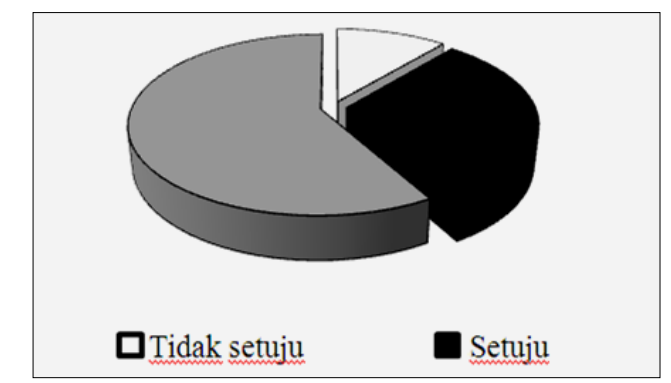

Gambar 12. Persepsi peserta tentang tahu merupakan makanan bergizi dan ole karenanya perlu dikonsumsi secara rutin

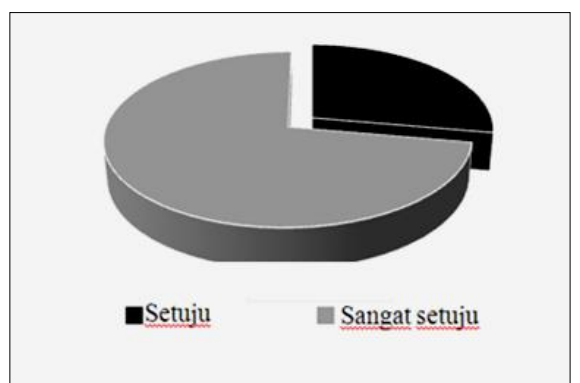

Gambar 13. Persepsi peserta tentang tahu merupakan makanan yang perlu dilestatikan

Tentang fasilitator, seluruh peserta mengatakan bahwa fasilitator memberikan materi dengan baik (47\% setuju dan 53\% sangat setuju) (Gambar 14). Gambaran umum dari persepsi positif tentang tahu tersebut juga terlihat dari peningkatan pengetahuan. Seluruh peserta (11\% setuju dan $89 \%$ sangat setuju) mengatakan bahwa pelatihan berhasil meningkatkan pengetahuan peserta tentang tahu (Gambar 15).

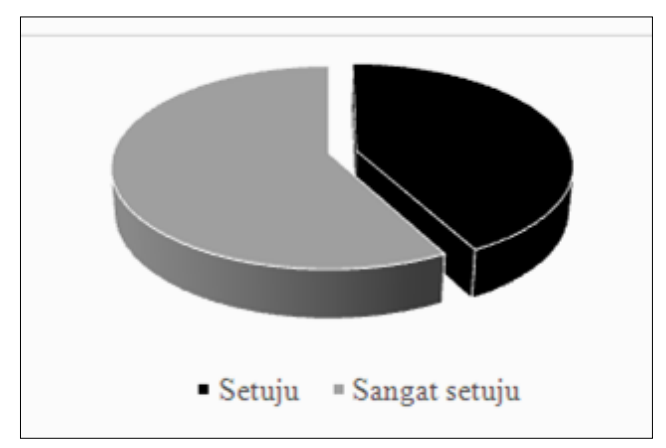

Gambar 14. Persepsi peserta tentang kualitas fasilitator dalam menyampaikan materi

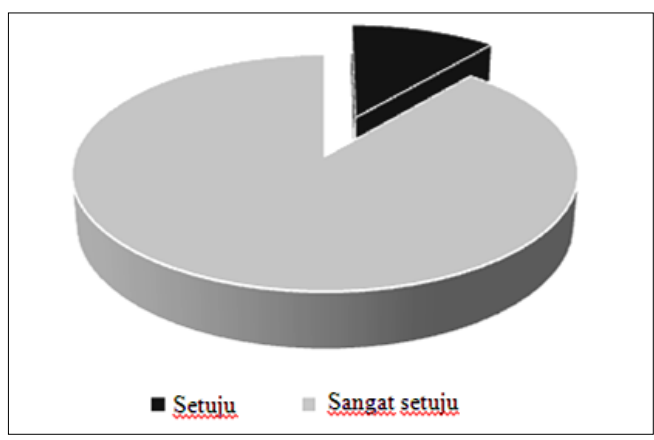

Gambar 15. Persepsi peserta bahwa pelatihan meningkatkan pengetahuan

Peningkatan pengetahuan tersebut tidak hanya tergambar dari persepsi peserta tapi juga tergambar dari hasil test, yakni peningkatan kemampuan peserta sesudah pelatihan (posttest) dibandingkan dengan sebelum ikut pelatihan (pretest) (Gambar 16). Peningkatan pengetahuan terutama nyata pada pengetahuan ilmiah tentang tahu, yakni fermentasi, proses maupun fungsi asam dalam proses penggumpalan tahu. Sedangkan untuk pengetahuan yang bersifat umum seperti manfaat tahu, tahu yang sehat dan bahan baku, peningkatannya tidak terlalu nyata. Perbedaan peningkatan kedua kelompok tersebut logis karena peserta mendapatkan penjelasan ilmiah tentang tahu selama pelatihan. Sedangkan pengetahuan umum tentang tahu, sebagian peserta umumnya telah mengetahuinya. 


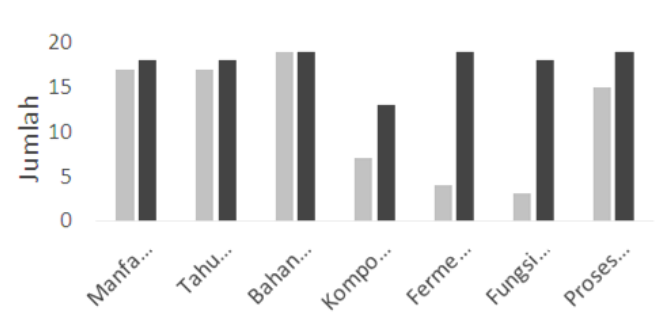

Gambar 16. Peningkatan pengetahuan pserta tentang tempe sesudah pelatihan (hitam) dibandingakn dengan sebelum pelatihan (abu-abu)

Keberhasilan utama dari kegiatan tentu diukur dari keberhasilan dalam meningkatkan ketrampilan dalam memproduksi sendiri tahu oleh para peserta. Seluruh peserta berhasil memproduksi tahu. Tahu yang sudah direbus kemudian langsung digoreng saat itu juga sehingga dapat langsung dinikmati (Gambar 17). Peserta langsung menikmati hasil praktik mereka dengan menyantap tahu yang digoreng menggunakan tepung dan bumbu sambal kecap yang disediakan panitia.

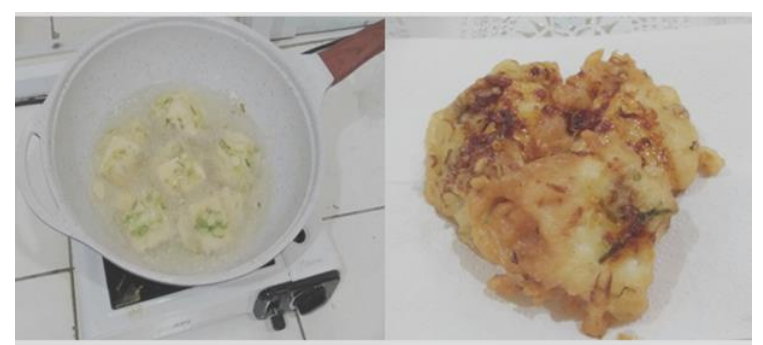

Gambar 17. Tahu hasil praktik peserta; tahu yang digoreng menggunakan tepung (kiri) dan tahu tepung yang sudah matang dibumbuin sambal kecap (kanan)

Monitoring yang dilakukan pada hari-hari berikutnya, terutama untuk memantau hasil pembuatan tahu. Seluruh peserta melaporkan hasil produksi tahu masing-masing. Sesudah pelatihan, mayoritas peserta melaporkan bahwa mereka sudah mempraktikkan sendiri pembutatan tahu di rumah masing-masing (Gambar 18). Monitoring dan kegiatan kegiatan para peserta membuat tahu di rumah masing masing terus berlangsung lewat WA, seperti gambar di bawah ini sebagai contoh.

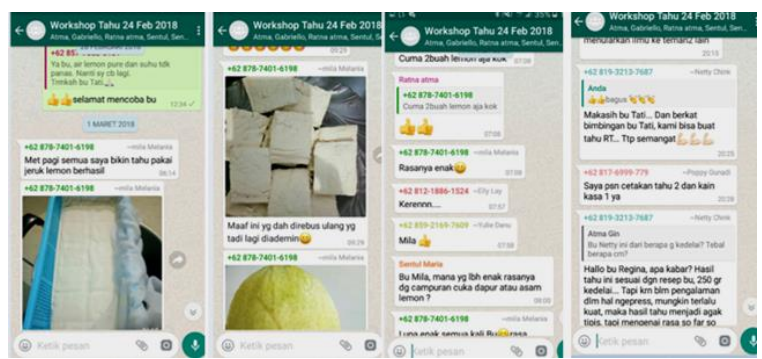

Gambar 18. Contoh diskusi melalui WA

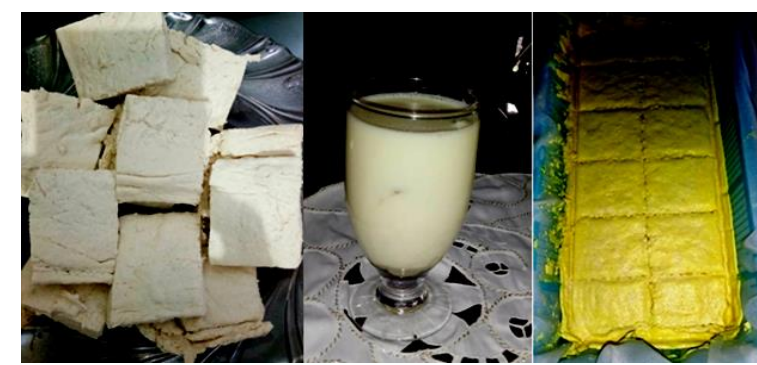

Gambar 19. Hasil praktik peserta setelah pelatihan: tahu dengan asam lemon (kiri), susu jahe (tengah) dan tahu kunyit (kanan)

Keberhasilan suatu kegiatan juga harus diukur dari dampak (scaling) dan keberlangsungannya (sustainability). Sesudah pelatihan, melalui grup WA ini telihat Ibu Yemima masih menginisiasi dengan menjadi penyalur pembelian bahan-bahan yang diperlukan, hal ini dapat menggerakkan peserta yang lain untuk terus membuat tahu. Dari hasil pelatihan ini, muncul terobosan-terobosan 
baru dari yang muncul dari pelatihan tahu ini yaitu bagaimana membuat tahu bulat, kembang tahu dan tahu sutera.

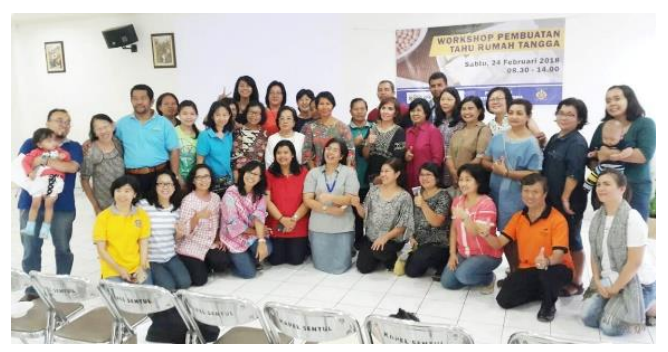

Gambar 20. Foto bersama di akhir pelatihan

\section{KESIMPULAN}

Pelatihan pembuatan tahu yang sehat berhasil meningkatkan pengetahuan dan meningkatkan ketrampilan untuk memproduksi sendiri tahu yang sehat oleh para peserta. Pelatihan berhasil membangun persepsi yang baik tentang tahu yang berdampak pada keinginan untuk memproduksi dan mengonsumsi tahu secara teratur. Hasil post test juga menunjukkan peningkatan pengetahuan yang signifikan tentang tahu terutama untuk aspek ilmiah (fermentasi, kedelai, fungsi asam dan lain-lain). Hasil utama dari kegiatan pengabdian yang sudah dilakukan terlihat dari kemampuan peserta membuat tahu dengan mengikuti prosedur pembuatan tahu yang sehat. Keberhasilan pelatihan diperkuat hasil monitoring dimana semua peserta berhasil membuat tahu yang sehat. Kegiatan pelatihan berhasil memotivasi peserta membuat tahu dalam skala rumah tangga secara mandiri dan satu dari peserta berhasil menjadi pengusaha tahu. Semua peserta mencoba membuat tahu dan menyarankan agar pelatihan diperluas untuk kalangan yang lebih luas. Proses pendampingan pembuatan tahu untuk mendapatkan tahu yang sehat juga berjalan dengan baik yang terlihat dari penilaian yang positif tentang proses pelatihan dan terutama dari penilaian peserta tentang kemampuan fasilitator. Dampak dari kegiatan pengabdian terlihat dari sosialisasi dan hasil sosialisasi melalui media sosial dan permintaan dan realisasi pelatihan sejenis pada daerah lain.

\section{REFERENSI}

Cahyadi, W. (2009). Analisis dan Aspek Kesehatan Bahan Tambahan Pangan. Jakarta: Bumi Aksara.

Direktorat Gizi Departemen Kesehatan. (1999). Daftar Komposisi Bahan Makanan Direktorat Gizi. Jakarta: Departemen Kesehatan RI.

Hsu RL, Lee KT, Wang JH, Lee YL, Chen PY. 2009. Amyloid-degrading ability of nattokinase mmfrom Bacillus subtilis natto. J. Agric. Food Chem. 57:503-8.

https://www.bps.go.id/statictable/2014/09/08/950/rata-rata-konsumsi-per-kapita-seminggubeberapa-macam-bahan-makanan-penting-2007-2016.html

Karyasa, I. W. (2000). Bangga Makan Tahu dan Tempe. Jakarta: Forum Diskusi Indonesia.

Rekha, C. R., \& Vijayalakshmi, G. (2011). Influence of processing parameters on the quality of soycurd (tofu). Journal of Food Science and Technology, 50(1), 176-180. doi:10.1007/s13197-011-0245-z

Sarkar PK, Hasenack B, Nout MJR. 2002. Diversity and functionality of Bacillus and related genera isolated from spontaneously fermented soya bean (Indian kinema) and locust beans (African soumbala). Int J. Food Microbiol 77: 175-186.

Terlabie NN, Sakyi-Dawson E, Amoa-Awua WK. 2006. The comparative ability of four isolates of Bacillus subtilis to ferment soybeans into dawadawa. Int J. Food Microbiol 106:145-152. 